\title{
Effect of membrane toxin 12 isolated from Naja naja atra on proliferation and invasion of human bladder cancer $\mathbf{E J}$ cells
}

\author{
DELIN YANG $^{1}$, JIANSONG WANG $^{1}{ }^{*}$, JUN LI $^{2}$, HAIFENG WANG ${ }^{1}$, \\ HUIHAI HE ${ }^{1}$, CHAO ZHANG ${ }^{1}$, KAI WANG ${ }^{1}$ and HONGYI XU ${ }^{1}$ \\ ${ }^{1}$ Department of Urology, The Second Affiliated Hospital of Kunming Medical University, Yunnan Institute of Urology, \\ Kunming 650101; ${ }^{2}$ The First Affiliated Hospital of Kunming Medical University, Kunming 650031, P.R. China
}

Received July 7, 2011; Accepted October 3, 2011

DOI: $10.3892 / \mathrm{mmr} .2011 .622$

\begin{abstract}
We investigated the effect of membrane toxin 12 (MT-12), isolated from Naja naja atra, a species of Chinese Cobra, on the proliferation and invasion of human bladder cancer EJ cells and studied its mechanisms using MTT assay, Transwell chamber invasion assay, scanning electron microscopy and flow cytometry. The results indicated that MT-12 inhibited the proliferation of bladder cancer cells in a dose-dependent manner. The half maximal inhibitory concentration $\left(\mathrm{IC}_{50}\right)$ after $72 \mathrm{~h}$ was $0.66 \mu \mathrm{g} / \mathrm{ml}$. The invasion of cells decreased with increasing doses of MT-12 $(0.125-0.5 \mu \mathrm{g} / \mathrm{ml}$, $\mathrm{P}<0.001)$. Expression of CXCR4 decreased with the effect of MT-12 for a particular concentration range $(0.125-0.5 \mu \mathrm{g} / \mathrm{ml})$. To conclude, MT-12 is capable of inhibiting the proliferation and invasion of bladder cancer EJ cells. This mechanism may be associated with reduced expression of $\mathrm{CXCR} 4$ protein.
\end{abstract}

\section{Introduction}

Invasion and metastasis are distinct features of malignant tumors, and metastasis is the main reason for failure of cancer treatment. Invasion and metastasis are affected by numerous factors, including the induction of angiogenesis, stroma adhesion, protein hydrolysis and movement, among others (1). Urinary bladder cancer is one of the most common types of cancer, and postoperative chemotherapy remains the most important auxiliary treatment method. However, the effectiveness of chemotherapy is reduced due to the toxic side effects. Studies in vivo and in vitro have shown that membrane toxin (MT) is capable of killing a variety of tumor cells $(2,3)$. Its anti-tumor mechanism is not yet completely understood, yet recent studies have shown that the destruction of the cell

Correspondence to: Dr Haifeng Wang, Department of Urology, The Second Affiliated Hospital of Kunming Medical University, Yunnan Institute of Urology, Kunming 650101, P.R. China E-mail: highphone@126.com

*Contributed equally

Key words: bladder carcinoma, membrane toxin 12, CXCR4, proliferation, invasiveness membrane structure and interference with DNA synthesis may be involved. Research also suggest that MT may be able to induce tumor cell apoptosis (4). Research of the effects of MT on liver, lung, breast, melanoma and colorectal cancer is common $(2,3,5)$. However, there are few studies that have been carried out on bladder cancer. This experimental study of the effects of purified membrane toxin 12 (MT-12) on the human bladder cancer EJ cell line is reported as follows.

\section{Materials and methods}

Materials. Purified MT-12 was obtained from the Laboratory of Animal Toxins, Kunming Institute of Zoology, Chinese Academy of Medical Sciences, China, as a gift. Its molecular mass is approximately $6700 \mathrm{Da}$. The human bladder cancer EJ cell line was obtained from the Key Laboratory of Kunming Medical University, China. The NIH3T3 cell line was purchased from the Kunming Institute of Zoology, Chinese Academy of Medical Sciences, China.

Study apparatus and reagents were obtained as follows: FACSCalibur flow cytometer (Becton Dickinson Co., USA); a $5 \% \mathrm{CO}_{2}$ incubator and centrifuge volume fraction (ThermoFisher Scientific, Germany); a Bio-Rad 450 microplate reader, an electronic balance (Test Instrument Changshu Double Jay); and an S-3000N scanning electron microscope; a volume fraction of $2.5 \%$ glutaraldehyde; mouse anti-human CXCR4 fluorescent antibody (Santa Cruz Biotechnology, Inc., CA, USA); CXCR4 goat anti-mouse monoclonal antibody (Santa Cruz Biotechnology, Inc.); RPMI-1640 (Gibco, Invitrogen, Paisley, UK).

Cell culture. The improved MTT method was used to study the effect of MT-12 on the proliferation of EJ cells as previously described (6). After the EJ cells reached the logarithmic growth phase, the cell concentration was adjusted to $5 \times 10^{4} / \mathrm{ml}$ and the cells were added into a 96 -well plate, $90 \mu \mathrm{l} /$ well. A total of five concentrations of MT-12, 0.0625, 0.125, 0.25, 0.5 and $1 \mu \mathrm{g} / \mathrm{ml}$, were used and each concentration was set in three parallel wells, $10 \mu \mathrm{l} /$ well. Soluble enzyme groups were constructed using 0.1 and $0.05 \%$ sodium chloride solution of equal volume. Negative control groups were constructed using $10 \mu 110 \%$ (volume) serum-free RPMI-1640, while blank control groups were constructed using $100 \mu \mathrm{l}$ of the above 
solution. Following this, cells were cultured in a $37^{\circ} \mathrm{C}, 5 \%$ (volume fraction) $\mathrm{CO}_{2}$ incubator and incubated for $72 \mathrm{~h}$. MTT (5 mg/ml), $20 \mu \mathrm{l} /$ well, was added and culture was continued for a further $4 \mathrm{~h}$. The dissolved solution was then added to the triple reduction products, $100 \mu \mathrm{l} /$ well. After $12 \mathrm{~h}$, the proliferation rate was determined by measuring the absorbance (A) using a microplate reader at $570 \mathrm{~nm}$ single wavelength optical density. These experiments were repeated three times. The inhibition rate of cell proliferation was calculated by the following formula: Inhibition rate $(\%)=\left(\mathrm{A}_{\text {control well }}-\mathrm{A}_{\text {treated }}\right.$ well $) /\left(\mathrm{A}_{\text {control well }}-\mathrm{A}_{\text {blank well }}\right) \times 100 \%$.

Construction of the invasion chamber and determination of invasiveness in vitro. In order to prepare the chemokine, NIH3T3 cells were cultured in a 5\% (volume fraction) $\mathrm{CO}_{2}$ incubator at $37^{\circ} \mathrm{C}$. When the cell density reached $90 \%$, the culture medium was discarded, serum-free RPMI-1640 was added and cells were placed in a $5 \%$ (by volume) $\mathrm{CO}_{2}$ incubator at $37^{\circ} \mathrm{C}$ for $24 \mathrm{~h}$. The cells were centrifuged for $10 \mathrm{~min}$ at the rate of $800 \mathrm{rpm}$, and the supernatants were collected. They were stored in the refrigerator at $-20^{\circ} \mathrm{C}$. A total of $100 \mu \mathrm{g}$ Matrigel was diluted (1:8) and used to evenly coat a Transwell chamber and was formed into colloidal particles by being cultured in a $5 \%$ (volume fraction) $\mathrm{CO}_{2}$ incubator at $37^{\circ} \mathrm{C}$ for $20 \mathrm{~min}$. We then placed the chamber on a clean desk under ultraviolet radiation overnight in order to obtain a dry and sterile Matrigel. The following day, we slowly added RPMI-1640 (300 $\mu \mathrm{l})$ (with a small trickle), and placed it in a $5 \%$ (volume fraction) $\mathrm{CO}_{2}$ incubator at $37^{\circ} \mathrm{C}$ for $30 \mathrm{~min}$, allowing the Matrigel to re-hydrate. The serum-free 1640 was aspirated, and $200 \mu \mathrm{l}$ EJ cell suspension fluid was added. The cell number was $2 \times 10^{5} / \mathrm{ml}$. We then added the prepared prechemokines into the chamber (24-well culture plate), $600 \mu \mathrm{l} /$ well and placed the Transwell in 24-well plates. We added the various concentrations $(0.125,0.25,0.5 \mu \mathrm{g} / \mathrm{ml})$ of MT-12 into the chamber and these were defined as the experimental groups. An equal volume of saline was used to treat the plasmin control group ( $10 \mu \mathrm{l} /$ well). They were cultured in a $5 \%$ (volume fraction) $\mathrm{CO}_{2}$ incubator at $37^{\circ} \mathrm{C}$ for $12 \mathrm{~h}$. After this time, the samples were removed and the nutrient solution was discarded. The cells were fixed with $90 \%$ (by volume) ethanol for $10 \mathrm{~min}$. The cells that did not pass through the cell membrane were wiped off carefully, and stained with $1 \mathrm{~g} / \mathrm{l}$ crystal violet at room temperature for $10 \mathrm{~min}$, and excess dye was rinsed clean with phosphate-buffered saline (PBS); 3 wells in each set. We then counted the number of invading cells under the microscope, a total of 12 fields, and the images were captured (x200 magnification) and calculated the number of invasive cells. The inhibition rate of cell invasion was calculated by the following formula: Inhibition rate $(\%)=$ (invasive cell count ${ }_{\text {control well }}$ - invasive cell count experimental well $/$ invasive cell count control well x $100 \%$.

Scanning electron microscopy. The optimal concentration of the MT-12 group in the experimental group was $0.5 \mu \mathrm{g} / \mathrm{ml}$, and the vehicle control group was designed using an equal volume of saline. After $12 \mathrm{~h}$, we removed the cells from the invasion chamber and added $2.5 \%$ (by volume) glutaraldehyde fixative to fix cells. We then observed the chamber invasion under a scanning electron microscope.
Table I. Effect of MT-12 on the proliferation of EJ cells.

\begin{tabular}{lc}
\hline Group & Inhibition rate $^{\mathrm{a}}$ \\
\hline Plasmin control group & 0 \\
MT-12 groups & \\
$0.0625 \mu \mathrm{g} / \mathrm{ml}$ & $2.85 \pm 3.71$ \\
$0.125 \mu \mathrm{g} / \mathrm{ml}$ & $5.71 \pm 1.58$ \\
$0.25 \mu \mathrm{g} / \mathrm{ml}$ & $9.50 \pm 1.31$ \\
$0.5 \mu \mathrm{g} / \mathrm{ml}$ & $22.61 \pm 3.57$ \\
$1 \mu \mathrm{g} / \mathrm{ml}$ & $80.58 \pm 1.59$ \\
\hline
\end{tabular}

${ }^{a}$ Values represented as the mean \pm SD. MT-12, membrane toxin 12 .

CXCR4 expression detected by flow cytometry. Bladder cancer cells were routinely cultured to the logarithmic phase, conventionally digested, adjusted to the concentration of $1 \times 10^{7} / \mathrm{ml}$ and seeded in 6-well plates $(2 \mathrm{ml} /$ well). After $24 \mathrm{~h}$, the time at which cells adhered to the 6-well plates, we added MT-12. The eventual concentrations of the experimental groups were $0.5,0.25,0.125 \mu \mathrm{g} / \mathrm{ml}$, respectively, and the control groups with saline were also fixed. After $24 \mathrm{~h}$, cells were prepared by trypsin digestion to the cell suspension (concentration of $1 \times 10^{6} / \mathrm{ml}$ ). Fluorescein-labeled CXCR4 monoclonal antibody $5 \mu \mathrm{l}$ was added into $100 \mu \mathrm{l}$ cell suspension, and another $100 \mu \mathrm{l}$ cell suspension was set as a control group. CXCR4 expression was determined by flow cytometry.

Statistical analysis. For the experimental data, SPSS 11.5 statistical package was used for ANOVA. Differences were significant at a P-value $<0.05$.

\section{Results}

MT-12 inhibits EJ cell proliferation in vitro. After the EJ cells were treated with MT-12 for $72 \mathrm{~h}$, the cell proliferation was significantly inhibited in a concentration-dependent manner (Table I). The half inhibitory concentration $\left(\mathrm{IC}_{50}\right)$ was $0.66 \mu \mathrm{g} /$ $\mathrm{ml}$.

Effect of MT-12 on invasiveness of EJ cells. Transwell invasion results revealed that EJ cells were capable of passing through the Matrigel matrix, which was covered by an artificial plastic polycarbonate membrane. In the plasmin control group, a large number of EJ cells permeated to the other side of the Transwell membrane. However, in the MT-12 experimental groups, the number of EJ cells that permeated to the other side of the Transwell membrane was reduced in a concentration-dependent manner (Figs. 1 and 2).

Scanning electron microscopy. The polycarbonate membrane covered with Matrigel was observed. Pores on the polycarbonate membrane were closed by plastic Matrigel. In vitro, the volume of bladder cancer EJ cells was relatively large and cells were oval in shape. EJ cells crossed through the Matrigel and the pores of the polycarbonate membrane and attached to the back of the Matrigel. In the control groups, the tumor cells 


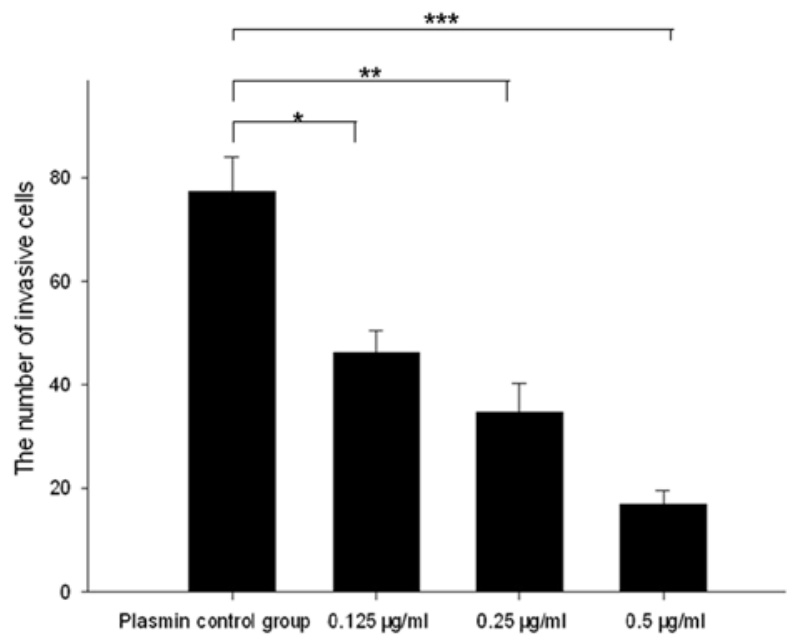

Figure 1. Number of invasive cells compared with the plasmin control group. "P $=0.006 ;{ }^{* *} \mathrm{P}=0.000 ;{ }^{* * *} \mathrm{P}=0.000$.
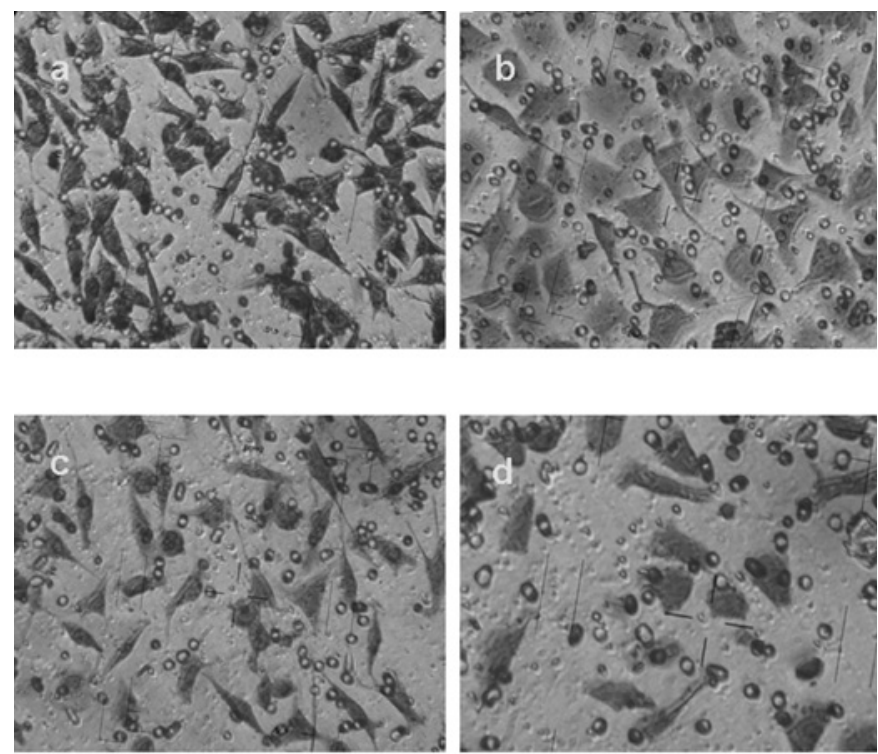

Figure 2. The invasive EJ cells after treatment with MT-12. (a) Plasmin control group. (b) MT-12 (0.125 $\mu \mathrm{g} / \mathrm{ml})$. (c) MT-12 $(0.25 \mu \mathrm{g} / \mathrm{ml})$ (d) MT-12 $0.5 \mu \mathrm{g} / \mathrm{ml})$.

had more microvilli and extended pseudopodia. In the experimental groups, the tumor cells had fewer surface microvilli and shorter pseudopodia (Fig. 3).

Effect of MT-12 on the CXCR4 protein expression of EJ cells. Compared with the control groups, the expression of CXCR4 decreased with the effect of MT-12 at a certain concentration range $(0.125-0.5 \mu \mathrm{g} / \mathrm{ml})$. However, there was no significant difference between the expression of CXCR4 and concentrations of MT-12 in this concentration range (Fig. 4).

\section{Discussion}

Bladder carcinoma is a common genitourinary cancer, and its malignant features of recurrence and metastasis are resistant to clinical treatments. The mechanism of tumor invasive
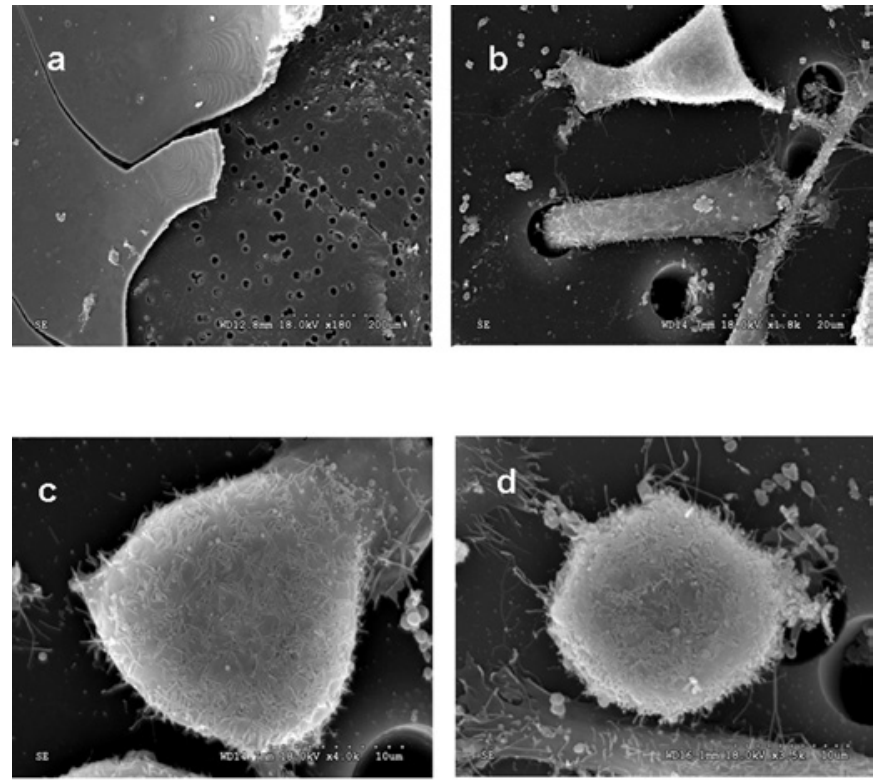

Figure 3. Results of scanning electron microscopy. (a) The edge of the membrane and pores on the polycarbonate membrane (x180). (b) Cells are stretching out pseudopodia and crossing through the membrane (x1800). (c) Cells of MT-12 $0.5 \mu \mathrm{g} / \mathrm{ml}$ group (x4000). (d) Cells of control group (x3500).
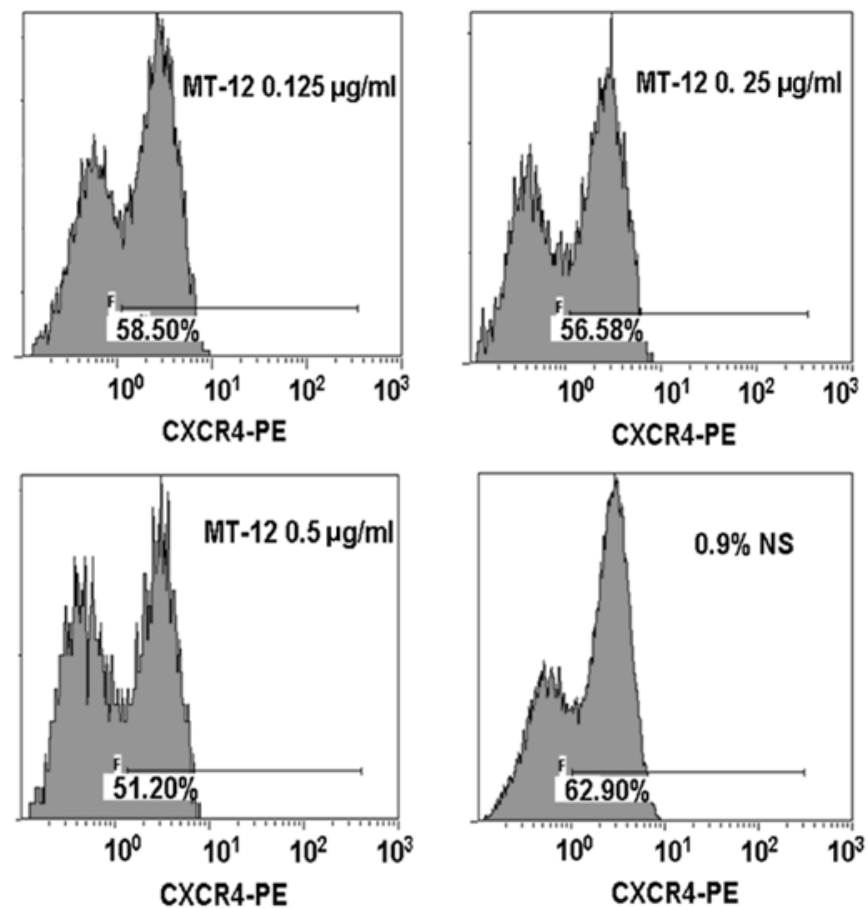

Figure 4. CXCR4 protein expression of EJ cells in the experimental and control groups. The comparison between the experimental group $(0.125 \mu \mathrm{g} / \mathrm{ml})$ and the control group $(\mathrm{P}=0.020)$.

growth is not yet clear. Invasion and metastasis are the main features of malignancy. In tumor cell migration, invasion and metastasis, chemokines and their receptors play essential roles. Chemokines refer to a large family with chemotactic cytokine chemicals. According to the end of the first two adjacent amino acid tyrosine positions, chemokines may be be 
divided into four categories: CXC, CC, C and CX3C. Through $\mathrm{G}$ protein-coupled transmembrane receptors, chemokines are able to play a role in tumor cell invasiveness. In 2001, Muller et al found that human breast cancer cell lines, breast cancer primary tumors and metastases highly expressed the chemokine receptors CXCR4 and CCR7 (7). CXCR4 is a G protein-coupled receptor, which consists of seven transmembrane domains. Recent research has revealed that this protein is known as a coreceptor for a foreign HIV. The expression of the chemokine receptor, CXCR4, has been shown to play a key role in migration and metastasis associated with tumor progression, and is associated with poor prognosis in a limited number of malignancies (8-11). We speculated that the expression of CXCR4 in malignant tumors may also be related to bladder cancer, and this role of $\mathrm{CXCR} 4$ makes it a potential target for prevention and treatment of tumor metastasis.

MTT results of this study revealed that MT-12 is capable of inhibiting the proliferation and invasion of human bladder cancer EJ cells in a dose-dependent manner; the $\mathrm{IC}_{50}$ of $\mathrm{EJ}$ growth was $0.66 \mu \mathrm{g} / \mathrm{ml}$. Tumor cells must destroy the extracellular matrix and basement membrane in order for metastasis to occur. Matrigel gel used in this study was similar to the extracellular matrix components and is capable of effectively stimulating the process of tumor cell invasion in vitro. The results of this study demonstrated that MT-12 inhibited the invasion of EJ cells compared with the negative control group, and with increases in MT-12 concentration, this inhibition efficiency was more marked, revealing that this occurred in a dose-dependent manner. When the concentration of MT-12 was $0.125,0.25$ and $0.5 \mu \mathrm{g} / \mathrm{ml}$, respectively, the invasion inhibition rates of EJ cells were 43.31, 55.30 and $78.29 \%$, which was significantly different compared with the control group $(\mathrm{P}<0.001)$. MT-12 at the $0.25 \mu \mathrm{g} / \mathrm{ml}$ concentration revealed a significant inhibitory effect and the invasion inhibitory rate was $55.30 \%$. However, at this concentration, the proliferation rate of EJ cells was $9.50 \%$. This suggested that the inhibition of EJ cell invasion was not significantly correlated with its cytotoxicity, and that inhibition appeared to be more sensitive. By using scanning electron microscopy, the process of invasion in vitro was observed. The characteristics of tumor cell invasion and the Matrigel assay was confirmed, providing a theoretical support for future research.

In conclusion, MT-12 is capable of inhibiting proliferation and invasion of bladder cancer cells. Furthermore, CXCR4 expression decreased compared with the control group. This enables us to make tentative assumptions that MT-12 is able to reduce the proliferation and invasion of bladder cancer EJ cells and may achieve this by reducing the expression of CXCR4. However, the related mechanisms of this inhibition must be studied in more detail.

\section{Acknowledgements}

This research was supported by Science and Technology Projects of Yunnan (no. 2008ZC135M), as well as the Collaborative Project of Provincial Science and Kunming Medical University (no. 2007C0016R).

\section{References}

1. Dachs GU and Chaplin DJ: Microenvironmental control of gene expression: implications for tumor angiogenesis, progression, and metastasis. Semin Radiat Oncol 8: 208-216, 1998.

2. Chien CM, Chang SY, Lin KL, et al: Taiwan cobra cardiotoxin III inhibits Src kinase leading to apoptosis and cell cycle arrest of oral squamous cell carcinoma Ca9-22 cells. Toxicon 56: 508-520, 2010.

3. Lin KL, Su JC, Chien CM, et al: Down-regulation of the JAK2/ PI3K-mediated signaling activation is involved in Taiwan cobra cardiotoxin III-induced apoptosis of human breast MDA-MB-231 cancer cells. Toxicon 55: 1263-1273, 2010.

4. Luo S, Hu I and Peng H: Chinese cobra venom fraction C of human hepatocellular carcinoma cell line B EL27402 apoptosis and telomerase activity[J]. Guangzhou Medical College 31: 126, 2003.

5. Tsai CH, Yang SH, Chien CM, et al: Mechanisms of cardiotoxin III induced apoptosis in human colorectal cancer colo205 cells. Clin Exp Pharmacol Physiol 33: 177-182, 2006.

6. Jun J and Le XF: Improved evaluation of anticancer activity of MTT method substances. Chin J Pharmaceut 24: 455, 1993.

7. Muller A, Homey B, Soto H, et al: Involvement of chemokine receptors in breast cancer metastasis. Nature 410: 50-56, 2001.

8. Kim RH, Li BD, Chu QD, et al: The role of chemokine receptor CXCR4 in the biologic behavior of human soft tissue sarcoma. Sarcoma 2011: 593708, 2011.

9. Lin F, Zheng SE, Shen Z, et al: Relationships between levels of CXCR4 and VEGF and blood-borne metastasis and survival in patients with osteosarcoma. Med Oncol 28: 649-653, 2011.

10. Schimanski CC, Schwald S, Simiantonaki N, et al: Effect of chemikine receptors CXCR4 and CCR7 on the metastatic behaviour of human colorectal cancer. Clin Cancer Res 11: 1743-1750, 2005.

11. Kato M, Kitayama J, Kazama S and Nagawa H: Expression pattern of CXC chemokine receptor-4 is correlated with lymph node metastases in human invasive ductal carcinoma. Breast Cancer Res 5: R144-R150, 2003. 